\title{
GENERAL PRINCIPLES OF INTERNATIONAL ENVIRONMENTAL LAW
}

\author{
Max Valverde Soto
}

I. SOVEREIGNTY AND RESPONSIBILITY ............................ 194

II. PRINCIPLES OF GOOD NEIGHBORLINESS AND

INTERNATIONAL COOPERATION ................................. 197

III. PRINCIPLE Of PREVENTIVE ACTION ............................. 199

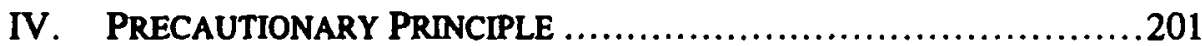

V. THE DUTY TO COMPENSATE FOR HARM ........................202

VI. PRINCIPLE OF COMMON BUT DIFFERENTIATED

RESPONSIBILITY ............................................205

VII. The Principle of Sustainable DeVelopment ...............205

A. Intergenerational Equity................................206

B. Sustainable Use of Natural Resources. ......................206

C. Integration of Environment and

Development. ..........................................207

This article is a description of the general principles and rules of international environmental law that have emerged from international treaties, agreements, and customs.' The significance of the generality of these principles is that they can be applied to the international community for the protection of the environment. ${ }^{2}$

Under traditional views, public international law derives from one of four sources: international conventions; international customs; general principles of law recognized by civilized nations; and judicial decisions

- Candidate for graduation at law from University of Costa Rica, 1996.

1. For the difference between general principles of law and general principles of international law, the latter discussed in here, see M. Virally. The Sources of International Law, in MANUal of Public INTERnational LAW 143 (1968). General principles of international environmental law may refer to rules of customary international law, to rules derived from treaties, to general principles of law as stated in article 38(I)(c) of the Statute of the International Court of Justice or to logical propositions resulting from judicial reasoning. Statute of the Intemational Court of Justice, 1945 I.C.J. Acts \& Docs. art. 38(I). See also G. Fitzmaurice, 2 General Principles Law, 92 HAGUE ReCUEIL (1957).

2. B. Cheng, General Principles of law as applied by international Courts AND TRIBUNAL 376 (1953). 
and teachings of highly qualified legal .scholars. ${ }^{3}$ Relatively new international environmental law is developing from the aforementioned sources, as well as from less traditional and binding sources.

There is no international instrument of global application which defines the rights and duties of the countries in environmental matters. Nevertheless, resolutions and declarations of international agencies in charge of the environmental controls, such as the Atomic Energy Agency, state the practices and decisions of international tribunals which have played important roles in the development of rules. From the large body of international instruments dealing with environmental issues, it is possible to point out seven principles. The consistency and acceptance is not the same for each, as will be shown.

\section{SOVEREIGNTY AND RESPONSIBILITY}

International environmental law has developed between two apparently contradicting principles. First, states' have sovereign rights over their natural resources. Second, states should not cause damage to the environment. Although the concept of a state's sovereignty over its natural resources is rooted in the old principle of territorial sovereignty, the United Nations General Assembly has further encouraged it declaring, inter alia, that the right of peoples and nations to permanent sovereignty over their natural resources and wealth must be exercised in the interest of their national development, and of the well-being of the people of the state. This resolution reflects the right to permanent sovereignty over natural resources as an international right, and has been accepted by tribunals as a reflection of international customs. ${ }^{5}$ National sovereignty over natural resources has been affirmed in international agreements. ${ }^{\circ}$

3. Statute of the International Court of Justice, supra note 1. See also L. HENKIN ET AL., INTERNATIONAL LAW 35 (1986).

4. Declaration on Permanent Sovereignty over Natural Resources Pe1803 (XVII) (Dec. 14, 1962); see also Declaration of the Right to Development, G.A. Res. 41/128 (Dec. 4, 1986).

5. Texaco Overseas Petroleum Co. and California Asiatic Oil Co. v. Libya, 53 I.L.R. 87 (Mar. 24, 1982); Kuwait v. Independent Am. Oil Co., 21 I.L.M. 976.

6. United Nations Education, Scientific and Cultural Organization Convention for the Protection of the World Cultural and Natural Heritage, Nov. 16, 1972, art. 15, 11 1.L.M. 1358,1363 [hereinafter UNESCO on Heritage]; United Nations Conference on Environmental Development: Convention on Biological Diversity, June 5, 1992, princ. 2, 31 I.L.M. 818 [hereinafter U.N. Convention on Biological Diversity]; Convention Relative to the Preservation of Fauna and Flora in their Natural State, Nov. 8, 1933, art. 9(6), 172 L.N.T.S. 241; Ramsar Convention on Wetlands of International Importance Especially as Waterfowl Habitat, Feb. 2, 1971, art. 2(3), 996 U.N.T.S. 245 [hereinafter Rasmar Convention on Wetlands]; International Tropical Timber Agreement, Nov. 18, 1983, art. 1, U.N. Doc. TD/TIMBER/ 11 Rev. 1 (1984); Basel Convention on the Control of Transboundary Movements of Hazardous Wastes and Their 
The concept of sovereignty is not absolute, and is subject to a general duty not to cause environmental damage to the environment of other states, or to areas beyond a state's national jurisdiction. As stated in the 1992 Rio Declaration:

states have, in accordance with the Charter of the United Nations and the principles of international law, the sovereign right to exploit their own resources pursuant to their own environmental and developmental policies, and the responsibility to ensure that activities within their jurisdiction or control do not cause damage to the environment of other states or areas beyond the limits of national jurisdiction.'

This is a derivation from the general maxim that the possession of rights involves the performance of corresponding obligations. ${ }^{\mathrm{s}}$

The responsibility not to cause environmental damage precedes the Rio Declaration. There is an obligation of all states to protect the rights of other states, as elaborated in Trail Smelter, ${ }^{9}$ a case which stated that:

under principles of international law ... no state has the right to use or permit the use of territory in such a manner as to cause injury by fumes in or to the territory of another of the properties or persons therein, when the case is of serious consequence and the injury is established by clear and convincing evidence. ${ }^{10}$

This principle was further developed in 1961 when the United Nations General Assembly declared that "[T]he fundamental principles of international law impose a responsibility on all states concerning actions which might have harmful biological consequences for the existing and future generations of peoples of other states, by increasing the levels of radioactive fallout." "The duty to avoid environmental damage also has

Disposal, Mar, 22, 1989, art. 12, 28 1.L.M. 649, 668; United Nations Conference on Environmental Development: Framework Convention on Climate Change, May 9, 1992, art. 14, 31 I.L.M. 849, 867 [hereinafter U.N. Convention on Climate Change].

7. See United Nations Convention on the Rio Declaration of Environment and Development, June 15, 1992, princ. 2, 31 I.L.M. 876 [hereinafter Rio Declaration].

8. See Advisory Opinion Namibia, 1971 1.C.J. 16.

9. Trail Smelter, REPORT OF THE UNITE NATIONS CONFERENCE ON THE HUMAN ENVIRONMENT, 11 I.L.M. 1416 (June 16, 1972) [hereinafter Stockholm Declaration].

10. United States v. Canada, 3 R.I.A.A. 1907 (1941). See also Nuclear Tests (Austl. v. Fr.), 1974 I.C.J. 253, 389 (dissenting opinion of Judge de Castro).

11. G.A. Res. 1629 (XVI) (1961). See also G.A. Res. 2849 (XXVI), para. 4(a) (1972). 
been accepted in international treaties ${ }^{12}$ as well as in other international practices. $^{13}$

Moreover, in the case of shared resources, this is a resource which does not fall as a whole within the jurisdiction of one state; the primary concept is the obligation for equitable and harmonious utilization of the resource." This obligation is primarily related to cooperation on the basis of a system of information and prior consultation and notification in order to achieve optimum use of such resources without causing damage to the legitimate interests of other states."s

In those areas beyond the limits of national jurisdiction, such as the high seas, the applicable concept is not one of sovereignty, but is one of common heritage of humanity. Simply stated, global property is open and its wealth cannot be appropriated by states. 'States are only administrators of the property's wealth and benefits. ${ }^{16}$ States must cooperate in the conservation and share the economic benefits of those areas." Recently,

12. Food and Agriculture Organization International Plant Protection Convention, Dec. 6, 1951, pmbl., 150 U.N.T.S. 68; Treaty Banning Nuclear Weapons Tests in the Atmosphere, in Outer Space and Under Water, Aug. 5, 1963, art. I(1)(b), 480 U.N.T.S. 43; African Convention on the Conservation of Nature and Natural Resource, Sept. 15, 1968, 4 U.N.T.S. 1001; UNESCO on Heritage, supra note 6, at ant 16(1)(b); Treaty for Amazonian Co-operation, July 3, 1978, art. IV, 17 I.L.M. 1045; Convention for the Protection of the Maritime Environment and Coastal Area of the South-East Pacific, Nov. 12, 1981, an. 3(5), International Environmental Legal Materials and Treaties 337; Association of South East Asian Nations Agreement on the Conservation of Nature and Natural Resources, July 1985, art. 20, 24 I.L.M. 1142; United Nations Convention on the Law of the Sea, Dec. 10, 1982, art. 193, 21 1.L.M. 1261 thereinafter Law of the Sea]. This last convention states that the obligation to prevent environmental harm is not only a negative obligation; there should also be positive action towards environmental protection.

13. See generally G.A. Res. 2996 (XXVII) (1972); Charter of Economic Rights and Duties of States, G.A. Res. 3281, art. 30 (1974); 1975 Final Act of the Helsinki Conference on Security and Cooperation in Europe, 14 I.L.M. 1292.

14. See, e.g., Helsinki Rules on the Uses of the Waters of International Rivers, Aug. 1966, in REPORT OF THE FIFTY-SECOND CONFERENCE OF THE INTERNATIONAL LAW ASSOCIATION 484 (1967).

15. See, e.g., G.A. Res. 3281, supra note 13, at ch. II, art. 3.

16. See generally A. KISS, Droit International de l'environnement, Paris, 1989; Nouvelles tendences en Droit Internationel de l'environnement, Y.B. INT'L L. (Dunker and Humboldt, Berlin eds., 1990).

17. See Law of the Sea, supra note 12, at arts. 136, 137, 140, 21 I.L.M. 1261; Treaty on Principles Governing the Activities of States in the Exploration and Use of Outer Space, Including the Moon and Other Celestial Bodies, Jan. 27, 1967, 610 U.N.T.S. 205 [hereinafter Treaty on Exploration and Use of Space]. 
the concept of common heritage of humankind has been applied to the protection of Antarctica. ${ }^{18}$

\section{PRINCIPLES OF GOOD NEIGHBORLINESS AND INTERNATIONAL COOPERATION}

The principle of good neighborliness places on states a responsibility not to damage the environment. The principle of international cooperation places an obligation on states to prohibit activities within the state's territory that are contrary to the rights of other states and which could harm other states or their inhabitants. ${ }^{19}$ This is considered to be an application of the maxim sic utere tuo, et alienum non laedas. ${ }^{20}$

The principle of good neighborliness is closely related to the duty to cooperate in investigating, identifying, and avoiding environmental harm. Most international environmental treaties have provisions requiring cooperation in the generation and exchange of scientific, technical, socioeconomic, and commercial information." This obligation to cooperate is not absolute. Instead, it is limited by municipal conditions such as the protection of patents. ${ }^{22}$

18. Protocol to the Environmental Protection to the Antarctic Treaty, Oct. 4, 1990, 30 I.L.M. 1461 (1991) (not in force). The concept of common heritage of humankind has been useful. Nevertheless, it provides a less compelling conceptual background for regulating such issues as the greenhouse effect and biodiversity protection. Therefore, another concept has evolved, the one of common concern of humankind. It has not been defined yet, and I believe it will never be defined. It is its vacuity which has made possible international regulation for activities that otherwise would fall under the internal jurisdiction of states.

19. International cooperation was dictated by the International Court of Justice in Corfu Channel (U.K. v. Alb.), 1949 I.C.J. (April 22). See also Lac Lanoux Arbitration (Spain v. Fr.), 12 R.I.A.A. 285 (Arbitral Tribunal affirmed "France is entitled to exercise her rights; she cannot ignore the Spanish interests."). Island of Palmas (U.S. v. Neth.), 11 R.I.A.A. 829; Alabama Claims Arbitration, 7; J. MOORE, DIGEST OF INTERNATIONAL LAW 1059-67; AMERICAN Mexican Claims Commission, Texas Cattle Claims Report to the SECRetary of STATE 51; United States v. Arjona, 120 U.S. 479 (1887); H. KELSEN, PRINCIPLES OF INTERNATIONAL LAW 96, 205-06 (1966).

20. The maxim was invoked as a rule by Hungary in the Gabcikovo-Nagymaros Project (Hung. v. Slovk.), 1992 I.C.J. 32. Hungary supported its submission in Corfu Channel; Stockholm Declaration, supra note 9; Rio Declaration, supra note 7, and the INTERNATIONAL LAW COMMISSION DRAFT ARTICLES ON STATE RESPONSIBILITY (1990).

21. See Law of the Sea, supra note 12, at art. 200; U.N. Convention on Biological Diversity, supra note 6, at art. 17; Convention on the Protection and Use of Transboundary Watercourses and International Lakes, Mar. 17, 1992, art. 8, 31 I.L.M. 1312; Convention for the Protection of the Ozone Layer, Mar. 22, 1985, art. 4, 26 I.L.M 1517 [hereinafter Ozone Protection Convention].

22. See Ozone Protection Convention, supra note 21, at art. 4; 26 1.L.M. at 1530-32; Law of the Sea, supra note 12 , at ant. 17. 
The exchange of general information is critical in monitoring the domestic implementation of international obligations. For example, a cooperative exchange of information regarding the trade of endangered wildlife is critical in tracing the population flow of animals..$^{23}$ The same occurs with greenhouse effect emissions. ${ }^{24}$ Due to the importance of exchanging information, some conventions have created separate international bodies with information generating and distribution functions. ${ }^{25}$ Additionally, many conventions contain provisions dealing with scientific knowledge, ${ }^{26}$ atmospheric changes, ${ }^{27}$ marine pollution, ${ }^{28}$ and cultural preservation. ${ }^{29}$

Other subprinciples embodied in good neighborliness and international cooperation are the principles of prior notification and consultation. Prior notification obligates acting states to provide prior, timely notification and relevant information to every state that may be adversely affected by its environmental activities. ${ }^{30}$ Of course, states shall immediately notify other states of any natural disasters or other

23. See Convention on the International Trade in Endangered Species of Wild Life and Flora, Mar.3, 1973, art. 7, 993 U.N.T.S. 243.

24. See U.N. Convention on Climate Change, supra note 6, at art. 12.

25. See id. at art. 9 (discussing the Conference of Parties created to advise on scientific and technological matters).

26. See generally Stockholm Declaration, supra note 9, at princ. 20; United Nations Environment Programme Governing Council Decision: Principles of Conduct in the Field of the Environment for the Guidance of States in the Conservation and Harmonious Utilization of Natural Resources Shared by Two or More States, May 19, 1978, 17 I.L.M. 1091 [hereinafter U.N. Convention on Conserving Shared Natural Resources].

27. See U.N. Convention on Climate Change, supra note 6, at ant. 15; Ozone Protection Convention, supra note 21, at art. 3. The Ozone Layer Convention is an important model for rapid reaction to environmental problems. An annex elaborates in great detail those areas needing coordinated scientific research. For example, the potential consequences of increased ultraviolet radiation on human health and the environment. This is a major reason for the success of the parties in the combat against ozone depletion.

28. See Law of the Sea, supra note 12, at art. 200.

29. See UNESCO on Heritage, supra note 6.

30. See Rio Declaration, supra note 7, at princ. 19; Montreal Rules of International Law Applicable to Transfrontier Pollution, Sept. 1982, Report of the Sixtieth Conference of the Int'l L Comm'n 1-3 [hereinafter Montreal Rules on Transfrontier Pollution]; U.N. Convention on Conserving Shared Natural Resources, supra note 26, at princ. 6; Law of the Sea, supra note 12, at art. 206. Special provisions can protect the disclosure of information as part of the notification requirement. See, e.g.. Organization of Economic Cooperation and Development Council Recommendation on Principles Concerning Transfrontier Pollution, Nov. 14, 1974, Annex, 14 I.L.M. 242 [hereinafter OECD Principles Concerning Transfrontier Pollution]; United Nations Environment Programme Governing Council Decision: Guidelines for the Exchange of Information on Chemicals in International Trade, May 1989, art. 11. 
emergencies that are likely to produce transboundary effects. ${ }^{31}$ Also, notification is particularly important when there is an oil spill, ${ }^{32}$ industrial mishap, ${ }^{33}$ or nuclear accident. ${ }^{34}$

Moreover, upon request, the acting state is bound to enter into a good faith consultation with potentially affected states over a reasonable period of time. ${ }^{3 s}$ However, the acting state is not bound by the opinions of the consulted states, but should take them into account. Finally, when one state is acting in the territory of another, notification and consultation is not enough. Prior informed consent is required. This consent is mandatory in activities such as transporting hazardous wastes through a state ${ }^{36}$ lending emergency assistance after an accident, ${ }^{37}$ and prospecting for genetic resources. ${ }^{38}$

\section{Principle of Preventive Action}

The pollution prevention principle should be differentiated from the duty to avoid environmental harm. Under this new rule, a state may be under the obligation to prevent damage within its own jurisdiction. ${ }^{39}$ Therefore, the discharge of toxic substances in such quantities or concentrations which exceed the capacity of the environment's degradation capacity, must be halted in order to ensure that serious or irreversible

31. Rio Declaration, supra note 7, at princ: 18.

32. International Convention for the Prevention of Pollution from Ships, Nov. 2, 1973, 12 I.L.M. 1319, 1434 (not in force).

33. Council Directive 82/501, art. 5, 1982 O.J.

34. United Nations Convention on Early Notification of Nuclear Accidents, Sept. 26, 1986. 25 I.L.M. 1377.

35. See Montreal Rules on Transfrontier Pollution, supra note 30, at art. 8; U.N. Convention on Conserving Shared Natural Resources, supra note 26, at princ. 6-7; OECD Principles Concerning Transfrontier Pollution, supra note 30, at princ. 7; Nordic Convention on the Protection of the Environment, Feb. 19, 1974, 13 I.L.M. 511.

36. Convention on the Control of Transboundary Movement of Hazardous Wastes and Their Disposal, Mar. 1989, art. 6(4), 28 I.L.M. 649; Organization of African Unity: Bamako Convention on the Ban of Import into Africa and the Control of Transboundary Movement and Management of Hazardous Wastes Within Africa, Jan. 29, 1991, art. 6, 30 I.L.M. 773, 785.

37. There is not an affirmative general obligation to provide emergency assistance if the helping state is not responsible for the damage. Nevertheless, assistance to the territory of the affected state has been stated in international instruments. See, e.g., Convention in Assistance in the Case of a Nuclear Accident or Radiological Emergency, Sept. 26, 1986, art. 2, 25 1.L.M. 1377; Rio Declaration, supra note 7, at princ. 18; Law of the Sea, supra note 12, at art. 199; U.N. Convention on Conserving Shared Natural Resources, supra note 26, at princ. 9(3).

38. U.N. Convention on Biological Diversity, supra note 6, at art. 15(5).

39. See Judge N. Singh, Foreword to Environmental Protection and Sustainable DEVELOPMENT: LEGAL PRINCIPLES AND RECOMMENDATIONS xi-xii (1986). 
damage is not inflicted upon ecosystems. ${ }^{\circ}$ Action should be taken at an early stage to reduce pollution, rather than waiting to restore contaminated areas.

To ensure this principle, states have established authorization procedures, commitments to environmental standards, ways to access information, the use of penalties, and the need to carry out environmental impact assessments." For example, environmental impact assessments have been incorporated as a decision-making instrument by international

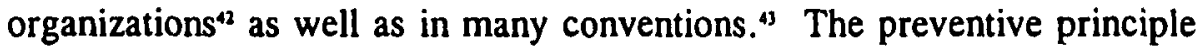
has been supported by international instruments preventing the introduction of pollutants, ${ }^{\mu}$ and also by agreements in the field of international economic law." Finally, it has also been endorsed by international case law. ${ }^{46}$

40. See Stockholm Declaration, supra note 20, at princ. 6. The preventive principle can be traced to 1933 with the Convention Relative to the Preservation of Fauna and Flora in their Natural State, supra note 6, which was framed to prevent the extinction of species of fauna and flora.

41. The environmental impact assessment is a procedure for examining, analyzing, and assessing proposed activities, prior to a decision, in order to minimize adverse effects. It involves governmental authorities, and when appropriate, public participation in the procedures.

42. See also World Bank Operational Directive 4.01 (1991); 1 WORLD BANK ENVIRONMENTAL. SOURCEBOOK 1990.

43. Rio Declaration, supra note 7, at princ. 17; Convention on the Regulation of Antarctic Mineral Resource Activities, Jan. 29, 1988, ants. 37(7)(d)-(e), 39(2)(c), 54(3)(b), 27 I.L.M. 68, princ. 11(c) [hereinafter Convention on Antarctic Minerals]; U.N. Convention on Biological Diversity, supra note 6 , at ant. 14.

44. See generally Convention for the Prevention of Marine Pollution from Land-Based Sources, Mar. 22, 1974, 13 I.L.M. 546; Convention on the Protection of the Mediterranean Sea Against Pollution, Feb. 15, 1976, 15 I.L.M. 290; Convention on the Protection and Use of Transboundary Watercourses and International Lakes, supra note 21; Convention on the Protection of the Alps, Nov. 7, 1991, 31 I.L.M. 767 (not in force). See also International Convention for the Prevention of Pollution of the Sea by Oil, May 12, 1954, 327 U.N.T.S. 3, pmbl.; Convention on the High Seas, Apr. 29, 1958, 450 U.N.T.S. 82, art. 25; Convention for the Prevention of Marine Pollution by Dumping from Ships and Aircraft, Feb. 15, 1972, 932 U.N.T.S. 3, ant 1; Law of the Sea, supra note 12, at an. 194(1); Convention Concerning Fishing in the Waters of the Danube, Jan. 29, 1958, 339 U.N.T.S. 23, at art. 7; Treaty Banning Nuclear Tests in the Atmosphere, in Outer Space and Underwater, supra note 12, at art. 1(1); Convention on Long-Range Transboundary Air Pollution, Nov. 13, 1979, 18 I.L.M. 1442, art. 2; Convention for the Protection of Natural Resources and the Environment of the South Pacific Region, Nov. 25; 1986, 26 I.L.M. 38, art. 5(1).

45. African, Caribbean and Pacific States-European Economic Community: Fourth Lomé Convention, Dec. 15, 1989, 29 I.L.M. 783, art. 35 (not in force); Treaty on European Union, Feb. 7, 1992, art. 130r(2), 31 I.L.M. 247.

46. See Certain Phosphate Lands in Nauru (Nauru v. Aus.), 1992 I.C.J. 240, 244. 


\section{Precautionary Principle}

This rule, although still evolving, is reflected in principle fifteen of the Rio Declaration, which states that where there are warnings of serious or irreversible damage, lack of full scientific certainty shall not be used as a reason for postponing cost-effective measures to prevent environmental degradation." Since scientific certainty often comes too late for politicians and lawyers to protect against environmental danger, the burden of proof is switched. To wait for scientific proof regarding the impact of pollutants discharged into the environment could result in irreversible damage to the environment and human suffering. Traditionally, states wishing to adopt certain protective measures had to prove beyond a doubt the hazard and the urgency of the desired action. ${ }^{48}$ Fortunately, because of the precautionary principle, this traditional view of burden of proof was reversed so that a state would not have to wait for proof of harm before taking action. Another possible interpretation of the shift in the burden of proof is that states wishing to undertake certain activities will have to prove that the activities will not cause harm to the environment.99

The first treaty to embody this principle is the 1985 Vienna Convention for the Protection of the Ozone Layer..$^{\text {so }}$ Subsequently, the precautionary approach for the protection of the environment has been widely addressed." Regrettably, there exists no precision as to the principle's requirements, and its formulations vary. What remains ambiguous is the level at which the lack of scientific evidence can not be claimed as an argument to postpone measures.

47. Rio Declaration, supra note 7 , at princ. 15.

48. See, e.g., Convention for the Prevention of Marine Pollution from Land-Based Sources, supra note 44, at art. 4(4).

49. This interpretation has been adopted in the Convention for the Protection of the Marine Environment of the North-East Atlantic, Sept. 22, 1992, 32 I.L.M. 1069, Annex II, art. 3(3)(c). Under this agreement, the parties have to report the results of scientific studies which show that any dumping operations of radioactive wastes would not result in hazards to humans, living resources, and other uses of the sea. Id.

50. See Ozone Protection Convention, supra note 21, at pmbl.

51. See id. at art. 2(2)(a); Convention for the Protection of the Marine Environment of the Baltic Sea Area, Apr. 1992, 30 1.L.M. (1992) (not in force); Ministerial Declaration of the International Conference on the Protection of the North Sea, Bremen, Nov. 1, 1984; Ministerial Declaration of the Second North Sea Conference, London, Nov. 25, 1987; Third North Sea Conference, The Hague, Mar. 8, 1990; Ministerial Declaration on Sustainable Development in the European Economic Community Region, Bergen, May 16, 1990; Convention on the Ban of Import into Africa and the Control of Transboundary Movement and Management of Hazardous Wastes within Africa, supra note 36, at art. 4(3)(f). 
When can a preventive action be legally required? While the 1991 Bamako Convention ${ }^{22}$ links the preventive and precautionary principles and does not require the possibility of damage to be serious (lowering the level at which the lack of scientific evidence launches action), ,s the 1992 Convention for the Protection of the Marine Environment of the NorthEast Atlantics increases the threshold needed to implement preventive measures,"s requiring more than a mere possibility of damage.

\section{THE DUTY TO COMPENSATE For HARM}

States are responsible to ensure that activities within their jurisdiction or control do not cause damage to the environment of other states or areas beyond the limits of their national jurisdiction. Injuries result from violations of this generally accepted rule.s6 Any state responsible for a violation of international law has to stop the wrongful conduct and re-establish the condition that existed prior to the wrongful conduct. If it is impossible to re-establish the pre-existing condition, the state should provide compensation. ${ }^{37}$ An illegal or wrongful act exists where: a) conduct consists of an action or omission imputed to a state under international law; and b) such conduct constitutes a breach of an international obligation of the state. ${ }^{58}$ This definition poses three problems

52. Organization of African Unity: Bamako Convention on the Ban of the Import into Africa and the Control of Transboundary Movement and. Management of Hazardous Waste Within Africa, Jan. 29, 1991, 30 1.L.M. 773.

53. According to the ar. $4(3)(f)$ of the Bamako Convention, parties have to adopt and implement "the preventive, precautionary approach to pollution which entails, inter alia, preventing the release into the environment of substances which may cause harm to humans or the environment without waiting for scientific proof regarding such harm." Id. This formulation also links the preventive and precautionary approaches.

54. Convention for the Protection of the Marine Environment of the North - East Atlantic, supra note 49.

55. According to art. 2(2)(a) of the Convention for the Protection of the Marine Environment of the North - East Allantic, preventive measures are to be taken when there are "reasonable grounds for concern ... even when there is no conclusive evidence of a causal relationship between the inputs and the effects." Convention for the Protection of the Marine Environment of the North East Atlantic, supra note 49. This Agreement also links the preventive and precautionary approaches.

56. See Stockholm Declaration, supra note 20, at princ. 21; Rio Declaration, supra note 7. at princ. 2.

57. R. Wolfrum, Reparation for Intermational Wrongful Acts, ENCYCLOPEDIA OF PUBLIC INTERNATIONal LaW 352; See also Certain German Interests in Polish Upper Silesia (the so called Factory at Chorzow case) (F.R.G. v. Pol.), 1928 P.C.I.J. (ser. A) No. 17, at 377 (Sept. 13): RESTATEMENT (THIRD) OF THE FOREIGN RELATIONS LAW OF THE UNITED STATES $§ 901$ (1986).

58. Draft Articles on State Responsibility, [1980] 2 Y.B. Int'। L. Comm'n 30-4. 
in relation to international environmental law. First, what is the criteria for imputing liability to a state? Second, what is the definition of environmental damage? Third, what is the appropriate form of reparation?

With regards to the first question, there are three options: fault (negligence), strict liability (there is a presumption of responsibility but defenses are available), ${ }^{39}$ and absolute liability (no cause of justification is possible, and a state would be liable even for an act of God). While fault is based on due diligence, strict and absolute liability impose responsibility for acts not prohibited under international law. Strict liability emphasizes the harm rather than the conduct.

It is a widespread opinion that international law lacks absolute or strict liability as a general rule. ${ }^{60}$ There is no single basis of international responsibility applicable in all circumstances, but rather several, the nature of which depends upon the particular obligation in question. ${ }^{61}$ Therefore, international law is not conclusive on the standard of care to be shown in the fulfillment of environmental obligations. For example, strict liability for ultra-hazardous activities can be considered a general principle of law since it is found in municipal legislation worldwide. ${ }^{62}$ Some treaties even support absolute liability for these activities. ${ }^{63}$ However, strict or absolute liability is more difficult to impute for activities that are not ultrahazardous. ${ }^{*}$. It should also be considered that the damage can be produced directly by state organs, by private individuals within the territory, ${ }^{65}$ or in the execution of lawful measures. ${ }^{66}$

59. I. Brownlie, System of the Law of Nations, State Responsibility, Part I, at 44 (1983). See also, The Corfu Channel Case, 1949 I.C.J. 4, 85-86 (April 9) (Azevedo, J., dissenting).

60. M. SORENSEN, MANUAL OF INTERNATIONAL LAW 539 (1968).

61. 1 L. OPPENHEDM, INTERNATIONAL LAW 509 (1955).

62. 11 A. TUNC, INTERNATIONAL ENCYCLOPEDIA OF COMPARATIVE LAW chap. V.

63. See Convention on International Liability for Damage Caused by Space Objects, Mar. 29, 1972, 961 U.N.T.S. 187, art II.

64. Some conventions contain exculpatory provisions for force majeure (a state is involuntarily placed in a situation which makes it materially impossible to adopt a conduct in conformity with international obligations) and distress (conformity with the obligation is possible but would result in loss of life). See, e.g., Law of the Sea, supra note 12, at art. 18(2), 39(1)(e); International Convention for the Prevention of Pollution of the Sea by Oil, supra note 44, at art. v.

65. See British Property in Spanish Morocco, 2 R.I.A.A. 642 (1925), where the arbitrator Max Huber, on the damage caused by private individuals to British property in Spanish Morocco, declared that "a state is obliged to exercise certain vigilance . . . ."

66. For example, Italian property was sequestered in Tunisia by the French Government after Italy's defeat in World War II: Case Comment, in re Rizzo, 22 INT'L L. REV. 322 (1955). The Conciliation Commission said: "the act contrary to international law is not the measure of 
As to the second question, environmental damage should be defined as a result of a violation of international law. This presents a dilemma since customary international law is still emerging and some environmental treaties rely heavily on voluntary cooperation. In addition, environmental damage has been defined as any injury to natural resources as well as ${ }^{61}$ degradation of natural resources, property, ${ }^{\infty}$ landscape, and environmental amenities. ${ }^{69}$ declared:

Finally, focusing on reparation, the Permanent Court of Justice

The essential principle contained in the actual notion of an illegal act . . . is that reparation must, as far as possible, wipe out all the consequences of the illegal act and reestablish the situation which would, in all probability, have existed if that act had not been committed. Restitution in kind, or if it is not possible, payment of a sum corresponding to the values which a restitution in kind would bear; the award, if need be, of damages for loss sustained which would not be covered by restitution in kind or payment in place of it - such are the principles which should serve to determine the amount of compensation due for an act contrary to international law. ${ }^{10}$

The problem is that at the environmental level, an identical reconstruction may not be possible. An extinct species cannot be replaced. However, at the very least, the goal should be to clean-up the environment and restore it so that it may serve its primary functions. But, even if restoration is physically possible, it may not be economically feasible. Moreover, restoring an environment to the state it was in before the damage could involve costs disproportionate to the desired results. Such elements, combined with the lack of legal precedent and the insufficiency of the traditional state's inability to assess environmental damage, makes the panorama difficult."

sequestration, but an alleged lack of diligence on the part of the French State . . . in the execution of the said measure." Id.

67. See generally Convention on Antarctic Minerals, supra note 43.

68. Draft Articles on State Responsibility, supra note 58, at art. 24.

69. See generally Convention on Civil Liability for Damage Resulting From Activities Dangerous to the Environment, June 21, 1993, 32 I.L.M. 1228.

70. See Certain German Interests in Polish Upper Silesia (F.R.G. v. Pol.), 1928 P.C.I.J. (ser. A) No. 17, at 377 (Sept. 13).

71. See Communication from the European Community Commission to the European Community Council and European Parliament on Environmental Liability, p. 32 (1993). 


\section{PRINCIPLE OF COMMON BUT DIFFERENTIATED RESPONSIBILITY}

The protection of the environment is a common challenge to all countries. Due to different development paths and the need to share in the responsibility for ecological degradation, some countries may be asked to carry more of the burden of conservation. The idea is that states should comply with international obligations for the conservation of the environment on the basis of equity and in accordance with their common but differentiated responsibilities and respective capacities. This principle was acknowledged in the Rio Declaration at principles four and seven.

This principle includes two constituent elements. The first is the common responsibility of states for the protection of the environment. ${ }^{22}$ This signifies that states should participate in the world effort for conservation. The second element is the elucidation of the different circumstances of states. ${ }^{3}$ For example, industrialized countries have contributed more to the global warming than underdeveloped countries. On the other hand, the capacities of developing countries to prevent damage may be less advanced. Also, the environmental policies of states should enhance and not affect the present and future development of developing countries." While all states are bound to participate in the environmental solution, the adoption of national standards and international obligations can differ. For example, the time period for the national implementation of preventive measures can vary from country to country. ${ }^{\text {s }}$

\section{The Principle of Sustainable DeVelopment}

The principle of sustainable development was defined by the 1987 Brundtland Report ${ }^{76}$ as a development that meets the needs (in particular the essential needs of the world's poor) of the present without

72. See Convention for the Establishment of an Inter-American Tropical Tuna Commission, May 31, 1949, 80 U.N.T.S. 72, at pmbl.; Rasmar Convention on Wetlands, supra note 6, at pmbl.; UNESCO on Heritage, supra note 6, at pmbl.; Treaty on Exploration and Use of Space, supra note 17, at art. 1; G.A. Res. 43/53 (1988), 44/207 (1989), 45/212 (1990).

73. See Stockholm Declaration, supra note 9, at princ. 23; Rio Declaration, supra note 7. at princs. 11, 6; Convention for Co-operation in the Protection and Development of the Marine and Coastal Environment of the West and Central African Region (Abidjan), March 28, 1981, art. 4(1), 20 I.L.M. 746; U.N. Convention on Climate Change, supra note 6, at pmbl.; Ozone Protection Convention, supra note 21, at art. 2(2); Law of the Sea, supra note 12, at art. 207.

74. See G.A. Res. 3281, supra note 13, at art. 30.

75. See Protocol on Substances that Deplete the Ozone Layer, Sept. 16, 1987, art. 5(1), 26 I.L.M. 1541 (which entitles the developing countries to delay their compliance with control measures if some requirements are met).

76. Report of the World Commission on Environment and Development (the Brundtland Report). 
compromising the ability of future generations to meet their own needs. It imposes the idea of limitations on the environment's capacity to meet present and futures needs."

Sustainable development prompts that the primary focus of environmental protection efforts is to improve the human condition." According to the anthropocentric approach, the protection of wildlife and natural resources is not a goal in itself, but is a necessity for ensuring a higher quality of life for humans.

Sustainable development, as reflected in international agreements, encompasses at least three elements:

\section{A. Intergenerational Equity.}

Intergenerational equity is each generation's responsibility to leave an inheritance of wealth no less than what they themselves have inherited. The present generation holds the natural resources in trust for future generations. ${ }^{79}$ Early ${ }^{80}$ and recent ${ }^{81}$ treaties have referred to this principle.

\section{B. Sustainable Use of Natural Resources.}

The primary roots of the principle of sustainable use of natural resources can be traced to 1893 , when the United States proclaimed a right to ensure the proper use of seals in order to save them from destruction. ${ }^{82}$ The term has been used in conservation conventions. ${ }^{83}$

While attempts to define the principle of sustainable use of natural resources have been made, no general definition exists. Terms such as

77. Id.; Our Common Future, 43 (1987).

78. See Rio Declaration, supra note 7, at princ. 1.

79. E. Brown Weiss, Our Rights and Obligations to Future Generations for the Environment, 84 AM. J. INT'L. L. 198 (1990).

80. See International Convention for the Regulation of Whaling, Dec. 2, 1946, 161 U.N.T.S. 72, pmbl.; African Convention on the Conservation of Nature and Natural Resource, supra note 12, at pmbl.

81. Convention on International Trade of Endangered Species of Wild Fauna and Flora, Mar. 3, 1973, 993 U.N.T.S. 243, pmbl.; U.N. Convention on Climate Change, supra note 6, at ar. 3(1); U.N. Convention on Biological Diversity, supra note 6, at pmbl.

82. Bering Sea Fur Seals Fisheries Arbitration (Gr. Brit. v. U.S.), reprinted in J. MOORE., INTERNATIONAL ARBITRATIONS 755 (1893); see also Fisheries Jurisdiction (U.K. v. Ice.) 1974 I.C.J. 34-35, where the obligation to cooperate in the conservation and sustainable utilization of global commons, including living resources on the high seas, was upheld.

83. Agreement on the Action Plan for the Environmentally Sound Management of the Common Zambezi River System, May 28, 1987, 27 I.L.M. 1109, pmbl.; U.N. Convention on Biological Diversity, supra note 6, at ants. 1, 8, 11, 12, 16-18; U.N. Convention on Climate Change, supra note 6 , at art. 3(4). 
proper," wise use, ${ }^{85}$ judicious exploitation, ${ }^{86}$ sound environmental management, ${ }^{87}$ ecologically sound, and rational use ${ }^{88}$ are used interchangeably without definitions.

\section{Integration of environment and development.}

"In order to achieve sustainable development, environmental protection shall constitute an integral part of the development process and cannot be considered in isolation from it." 89 Therefore, when implementing environmental obligations, economical and social development should be taken into consideration, and vice versa.

Although traditionally international organizations such as the World Bank or the World Trade Organization never addressed environmental protection, a change is slowly coming. ${ }^{90}$ Regarding macroeconomics, the move towards sustainable development requires, for example, new accounting systems to evaluate a country's progress. The accounting system would include pollution control efforts and environmental damage when calculating the gross national product (GNP). Mining extraction, for example, would not simply reflect an increase in the GNP, but also a reduction in natural resources." In microeconomics, sustainable development would require, for example, imposition of the costs of environmental damage on the state which caused the damage. ${ }^{2}$

84. FAO Agreement for the Establishment of a General Fisheries Council for the Mediterranean, Sept. 24, 1949, 126 U.N.T.S. 237, art. IV(a).

85. Convention on the Conservation of Migratory Species of Wild Animals, June 22, 1979, pmbl., 19 I.L.M. 15 (1980).

86. Act Regarding Navigation and Economic Co-operation between the States of the Niger Basin. Oct. 1963, pmbl., 587 U.N.T.S. 9.

87. Convention for the Protection and Development of the Marine Environment of the Wider Caribbean Region, Mar. 24, 1983, art. 4(1), 22 I.L.M. 221.

88. UN/ECE Convention on the Transboundary Effects of Industrial Accidents, Mar. 17, 1992, art.2(2)(b), 31 1.L.M. 1333.

89. See Rio Declaration, supra note 7 , at princ. 4 .

90. See E. Iglesias, El papel de los organismos multilaterales de cooperación en el desarrollo sostenible: $e l$ caso de BID, 20 REVISTA DE CIENCIAS SOCIALES IBEROAMERICANAS DE LA ASOCIACIÓN DE INVESTIGACIÓN Y ESPECIALIZACION SOBRE TEMAS IBEROAMERICANOS 147-57 (1993).

91. See generally STATISTICAL OFFICE OF THE UNITED NATIONS, DRAFT HANDBOOK ON INTEGRATED ENVIRONMENTAL AND ECONOMIC ACCOUNTING (1992).

92. This is the polluter pays principle, which implies that the polluter should bear the expenses of carrying out pollution prevention measures or paying for damage caused because the environmental costs of production were not internalized. 
The integration of environment and development can be traced to the 1949 United Nations Conference on Conservation and Utilization of Resources," which recognized the need for "continuous development and wide-spread application of the techniques of resource conservation and utilization." Regional"s and global\% treaties are also taken into consideration under this approach.

\section{CONCLUSION}

The legal meaning and consequences of the above stated principles remain open. Some have evolved over a short period of time and sometimes in different contexts. Additionally, state practice is also evolving. Another element which complicates the environmental field is that some of the principles have no definite meaning. There is also no agreement concerning the legal consequences of these rules. Together, this makes it difficult to compel the international community to protect the environment.

The rules of permanent sovereignty over natural resources, the responsibility to prevent environmental damage, good neighborliness, and cooperation in relation to environmental protection are well established and rooted in state practice and international instruments. Even more, permanent sovereignty can be regarded as customary international law.

On the other hand, the duty to compensate for environmental harm can be considered a corollary of the general duty to compensate for damages provoked by international wrongful acts. Nevertheless, the difficulty to assess the environmental damage within the existing liability rules makes the application of the rules problematic. Also, there is no agreement as to the applicable type of responsibility (subjective or objective). Notwithstanding, the trend is to avoid these vague notions and define the state-required conduct necessary to prevent harm to other states. Therefore, the obligation to avoid environmental harm would be stated as an obligation to take certain measures to ensure that activities within the control of the state conform to international environmental protection

93. United Nations Conference on Conservation and Utilization of Resources.

94. U.N. Res. 32(IV), Environmental and Social Council, pmbl. (1947).

95. See Kuwait Regional Convention for Co-operation on the Protection of the Marine Environment from Pollution, Apr. 24, 1978, 1140 U.N.T.S. 133; Treaty for Amazonian Cooperation, supra note 12.

96. U.N. Convention on Climate Change, supra note 6; Convention on Biological Diversity, supra note 6, at pmbl. 
standards. These rules of conduct will be the rules used to decide whether an agreement has been violated."

Preventive action and precautionary and sustainable development principles are more difficult to uphold, since they are rather new and vague concepts. However, they deserve attention, since they will undoubtedly shape the future development of international law. For example, if the principle of sustainable development quickly takes root in the international law regime, all developmental decisions could be subjected to environmental inquiry.

Finally, the influence of international litigation should not be underestimated. ${ }^{98}$ The decision of international tribunals such as the European Court of Justice (granted supra national adjudicative power within the European Community) $)^{\infty}$ and the International Court of Justice ${ }^{100}$ on environmental matters, will contribute to the codification of these principles.

97. See L. HENKIN ET AL., supra note 3, at 529.

98. But see Z. Plater et al., ENvironmental LAW AND POLICY: NATURE, LAW AND SOCIETY 1007 (1992).

99. P. SANDS, EuROPEAN COMMUNITY ENVIRONMENTAL LAW: LEgiSlation aNd THE EUROPEAN COURT OF JUSTICE (1991) (noting several recent cases strongly affirming environmental principles in interpretations of European legislation).

100. In July 1993, the court decided to establish a seven member Chamber on Environmental Matters in view of the developments in the field of environmental law and protection which had taken place in the past few years. 


\section{CREANDO UN MONDO DIFERENTE \\ La Sección de Ley y Práctica InTernacional del ABA}

\section{AFILIESE HOY MISMO!}

Aprovéchese de las oportunidades que la Sección le ofrece:

- Información actualizada de los últimos acontecimientos en ley internacional.

- Oportunidades para contactos profesionales.

- Participar en proyectos de asistencia técnica internacional y en los programas de intercambio legal y viajes informativos de ILEX.

- The International Lawyer - la aclamada revista jurídica trimestral.

- The International Law News - una publicación trimestral con importantes noticias sobre ley internacional.

Por encima de 58 comités dedicados a sus áreas de interés: comercio, inversión, arbitraje, telecomunicaciones, y también inmigración y nacionalidad, ley interamericana, y práctica transnacional.

Visite nuestra página electrónica en el WWW:

http://www.abanet.org/intlaw

Si desea recibir información para afiliarse llame al (202) 662-1034

\section{PUBLICACIONES DE LA SECCION}

\section{THE INTERNATIONAL LAWYER'S DESKBOOK}

Editado por Lucinda A. Low, Patrick M. Norton, y Daniel M. Drory

Este libro es la primera guia comprehensiva para resolver casos juridicos internacionales.

Es un valioso recurso para cualquier experto jurídico internacional.

$\$ 75.00$ para miembros, $\$ 85.00$ precio regular. (PC: $521-0106$ )

The World Trade Organization: MUltilateral Trade Framework' FOR THE 21ST CENTURY AND U.S. IMPLEMENTING LEGISLATION

Editado por Terence P. Stewart

Esta nueva publicación proporciona un resumen de la Organización Mundial del

Comercio y de los acuerdos alcanzados en la Ronda de Uruguay.

$\$ 80.00$ para miembros, $\$ 95.00$ precio regular. (PC: $521-0107$ )

\section{CAREERS IN INTERNATIONAL LAW}

Editado por Mark Janis

Este libro contiene información imprescindible para todo aquel interesado en iniciarse en el campo legal internacional.

\$14.99 para miembros, \$19.99 precio regular. (PC: 521-0086)

Disponibles a través de la Sección de Ley Internacional del ABA.

Para encargar llame al 800 285-2221 o (312) 988-5522 


\section{ILSA \\ JOURNAL OF INTERNATIONAL \& \\ COMPARATIVE LAW}

Volumen 3

1996 Otoño

Numero 1

\section{LISTA DE CONTENTO}

\section{ARTICULOS Y ENSAYOS}

La Actividad Reciente Antes de la Corte Internacional de la Justicia: La Tendencia O Ciclo? Gary L. Scott 213

Heather MacGregor Bothwell Jennifer Pennell

La Normativa Costarricense Sobre el Arbitraje Comercial y la Ley Federal Sobre Arbitraje. Jürgen Nanne Koberg 243

Contratación Entre un Empresa Japones y un Empresa Estadounidense: Las Diferencias en la Importancia de los Documentos Escritos Como el Acuerdo Final en el Japon y los Estados Unidos. Kizuki Kuzuhara

Un Estudio Comparativo de la Ley Judaíca y la Ley Constitucional de los Estados Unidos Sobre la Pena Capital Steven Davidoff 307

Usando Antimonopolio Estadounidense Para Interpretar La Ley De Competencia Costarricense Pedro M. Muñoz

\section{NOTAS Y COMMENTAPIOS}

Proscribiendo el Uso de Refugiados Como Instrumentos de la Política Extranjera................................ Geoffrey W. Hymans

Seguro de Credito para las Exportaciones y el Acuerdo General Sobre Aranceles y Comercio Rafael E. Cañas 393 Eric Scharf T.

El Tratado de Libre Comercio: Las Razones Sobre Su Adopción y los Requisitos para Ser un Consultante Legal Extranjero en un País Que Sea un Partido al NAFTA ... Michael J. Chrusch 399 Principios Generales Del Derecho Ambiental Internacional Max Valverde Soto 
La situación del mundo actualmente difiere en gran medida de la que se vivió hace algunos años. De igual forma, conforme pasa el tiempo, vemos como la forma en que se organiza la comunidad internacional cambia rápidamente. Surgen nuevas alianzas y uniones. La tecnología y los medios de comunicación permiten que mensajes le den vuelta al mundo en fracciones de segundo; y poco a poco vemos como la sociedad se acerca más a ser una comunidad global.

Esta nueva organización, a su vez, impone nuevos retos. Así, hemos sido testigos, y formamos parte de un proceso de homogeneización en la forma que se organizan sociedades originalmente distintas. El Derecho, por el papel que cumple dentro de la sociedad, está obligado asumir estos retos, y trascender las fronteras nacionales para ajustarse a estas nuevas circunstancias. El primer paso para hacerlo es, sin duda alguna, el conocimiento del medio.

De esta forma, sólo mediante el intercambio de ideas, a veces contrapuestas, se logra obtener una nueva realidad, que se ajuste a las nuevas necesidades de esta era. Gracias a esta constante dialéctica que surgen ideas como el presente proyecto, que a su vez, colabora con este proceso.

Por este motivo, aceptamos con gusto la propuesta del ILSA Journal of International \& Comparative Law de publicar, por vez primera, una revista de Derecho Internacional y Comparado totaimente bilingüe en inglés y español. Asociación Costarricense de Derecho Internacional (ACODI), una joven y ambiciosa asociación de estudiantes y abogados interesados en el Derecho Internacional, no podía desaprovechar esta oportunidad de trabajar al lado de esta organización y colaborar, en cierta forma, con el desarrollo del Derecho Internacional.

De esta forma, vivimos la experiencia no solo de formar parte en este proyecto único en su tipo; sino también de trabajar al lado de una organización con la experiencia y el conocimiento necesario para poder hacerlo. Extendemos nuestro eterno agradecimiento para los editores de esta revista por habernos hecho parte de este evento.

Por otro lado, recibimos también la invaluable colaboración de la Asociación Internacional de Estudiantes de Abogacía (AIEA), con sede en Mendoza, Argentina. Con su participación han ampliado aún más la perspectiva del proyecto, con lo que se logra un resultado aún más fructífero que el inicialmente previsto.

Finalmente, no queda más que colaborar con todos aquellos miembros de ACODI, que de muchas formas han colaborado para que esta publicación salga adelante.

Uri Weinstok M.

Coordinador de Publicaciones
Pamela Sittenfeld H. Coordinadora del Proyecto 